\title{
Farm Income Prospects ${ }^{1}$
}

$\mathbf{N}_{\mathrm{E}}$ less than the $\$ 14.9$ billion of 1968 , according to the United States Department of Agriculture. Gross farm receipts may rise, as larger supplies of farm products and little change in average prices are in prospect. Larger cash receipts from farm product sales, combined with an increase in government payments, are expected to push gross farm income to a record $\$ 52$ billion, about $\$ 1$ billion above the 1968 total. Production expenses are expected to rise more than a billion dollars, however, resulting in slightly less realized net income.

With the number of farms declining, net income per farm may remain at about the 1968 level, and per capita disposable income of farm population from all sources will probably continue its upward trend.

\section{Supply and Price}

The higher cash receipts in 1969 are contingent on the estimates of somewhat larger supplies of livestock products and crops, and little change in average prices from 1968 levels. A growing demand for food products, especially meat, will probably again offset the impact on prices of the larger livestock supplies, resulting in producer prices about the same as in

1A summary of information presented by U.S. Department of Agriculture representatives at the National Agricultural Ontm look Conference, Washington, D. C., February 17 to 20,1969 .
1968. Crop supplies in the 1968-69 marketing year are also larger than a year earlier. Little change is expected in the government price support and crop control programs for the current year, and crop prices will probably remain relatively unchanged.

\section{Livestock Products}

In the livestock sector, beef production is expected to continue its upward trend of recent years. The growth rates of the beef cow herd may be somewhat reduced, but cattle slaughter will likely continue upward. The number of cattle in feedlots on January 1, 1969 was 10 per cent more than a year earlier when fed cattle marketings of 23 million head during the year were the largest on record. Fed cattle slaughter should be well above 1968 levels, while little change in cow slaughter is anticipated. Despite the increase in beef output, prices are expected to hold at about the 1968 levels, due to the rising demand for meat.

The expansion of pig production which began in 1966 has been continuing, pointing to another increase in pork output in 1969. The gain this year may be a little larger than the 4 per cent increase last year and is not expected to be offset by an accelerat ing demand. Thus hog prices may average somewhat lower than a year earlier.

The downtrend of recent years in lamb slaughter ( 7 per cent less in 1968 than a year earlier) is ex- 
pected to continue. The livestock inventory of Jamuary 1, 1969 indicated a further reduction in sheep and lambs on farms.

Sizable gains over year-earlier levels are predicted for both broiler and turkey production. Broiler pro duction was up one per cent in 1968, the smallest year-to-year increase on record. Late in the year, however, production was 4 to 5 per cent above levels for the same months a year earlier, and this higher rate is expected to continue during the spring months in response to higher broiler prices and lower production costs during 1968. With the higher output in prospect, broiler prices are likely to fall below yearearlier levels and remain lower through the rest of the year.

The favorable cost/price relationship for turkeys in 1968 is also expected to cause an increase in turkey production. The number of turkeys produced in 1968 was down 16 per cent from a year earlier, but supplies were augmented by a large carry-over. Growers surveyed in January of this year intend to produce 3 per cent more turkeys than a year earlier. These indications point to a turkey output somewhat above the 1968 level but well below the record output of 1967. In view of this increase in production, turkey prices are not expected to average above the 1968 level.

Lower egg and milk production prospects point to somewhat higher prices for these commodities. Egg production may trail the 1968 level until the end of summer when a larger number of replacements will be moving into the laying flock. Thus prices to producers will probably remain well above year-earlier levels until late in the year when the replacement layers begin to produce. The price margin may then disappear. The number of dairy cows is expected to continue downward with a further increase in production per cow. Total milk production, however, is expected to be less, and smaller quantities will be purchased by the government through price support operations. Milk prices are likely to be somewhat higher than in 1968, reflecting the higher average government price supports and the anticipated decline in production.

\section{Crops}

The generally larger crop production in 1968, coupled with sizable carry-over stocks, provides larger crop supplies during the current marketing season than a year earlier. Expanding demand and the gov- ermment support program for major crops, however, point to little change in prices to producers.

The supply and use of feed grains are expected to be in closer balance in the current marketing year than in most recent years. Production was in excess of use during most of the 1950 's, and carry-over stocks held primarily by the government rose to excessive levels. During most of the 1960 's, however, production has been less than use, and carry-over stocks have declined. Production of 168 million tons in 1968 may be exceeded slightly by domestic use plus exports, which are likely to total about 148 and 22 million tons, respectively. Thus another slight reduction in carry over stocks is in prospect. Corn prices have advanced about 12 cents per bushel since the seasonal low last October, but with the large supplies subject to redemption under the loan program, and carry-over stocks of all feed grains expected to equal one-fourth annual use, prices of com are not likely to rise much above the loan level.

The 1969 feed grain program is essentially the same as in 1968. The acreage diversion program was extended to include barley. Also, some further reduction in carry-over stocks for all feed grains is planned.

The record 1968 wheat crop of 1,570 million bushels raised the supply in the current marketing year to 2,108 million bushels, the largest supply since the 1965-66 marketing year. Domestic use plus exports may total about 1,350 million bushels, leaving about 750 million bushels in carry-over stocks at the end of the marketing season, the largest carry-over since 1964. Prices during the current marketing year are not expected to average above the support rate of $\$ 1.25$ per bushel.

Rice supplies ( 1968 production plus carry-over) total 111 million hundredweight (cwt.), 15 million cwt. more than in the previous season and 32 million cwt. above the 1963-67 average. In recent years total rice usage has increased rapidly - about $10 \mathrm{million}$ cwt.

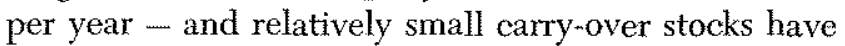
accumulated under the government price support program. Rice prices generally rose during the last mar keting season because of the large export demand. With the larger supplies this year, prices may remain nearer the support level of $\$ 4.65$ per cwt., which was raised $\$ 0.05$ per cwt. from the 1968 level.

The record 1968 crop of soybeans plus the 167 million bushel carry-over last September provides a supply of soybeans totaling 1,246 million bushels, well in excess of estimated utilization during the current market season. Soybean use is expected to rise mod. 
erately, but carry-over stocks will probably total more than 300 million bushels next September. With these excessive stocks, producer prices are likely to average near the support rate during the remainder of the 196869 marketing season. The price support level was $\$ 2.50$ per bushel for the 1968 crop. Price supports for 1969 had not been announced at the time of this writing.

The outlook for United States cotton contimues to be highlighted by competition from both synthetic fibers and foreign-produced cotton in the export market. Cotton's share of the domestic fiber market fell to 44 per cent in 1968 from 49 per cent in 1967, the sharpest decline on record. Cotton production abroad has been increasing faster than consumption for a number of years, and the gap is expected to narrow to 1.5 million bales this year. Pricing policies, which have ignored basic economic tenets by maintaining prices above the free market level, were a major factor in the development and growth of this competition.

Domestic use plus exports of cotton in the 1968-69 marketing season are expected to total about 11.5 million bales, or 1.5 million bales less than last year. Exports may decline about one million bales and domestic use about one-half million.

The relatively small cotton crops of the past two years ( 9.6 million bales in 1966 and 7.4 million bales in 1967) permitted a reduction in stocks of about 10 million bales. The 1968 crop was larger ( 10.8 million bales), but a further small reduction of 0.5 million bales in stocks is forecast for next August, which will bring carry over down to 6 million bales. This will be the smallest carry-over during the 1960 decade, but in view of the decline in cotton use, this level is still excessive for most types of cotton. Cotton prices are expected to remain near the government loan level during the remainder of the marketing season, and the government program for 1969 is designed to encourage a somewhat larger crop.

Tobacco supplies in the 1968-69 marketing year are about 5 per cent below levels of a year earlier. The 1968 crop was 13 per cent less and carry-over was down somewhat. Burley-type supplies are 2 per cent below last season and 7 per cent below the 1964-65 peak.
Use of major tobacco types in 1967-68 continued the slow downward trend of recent years, and little improvement from the producers' point of view is anticipated this year. Burley tobacco use in 1967 totaled 594 million pounds, down from 600 million pounds the previous year and 616 million pounds in 1964. Flue-cured tobacco use in 1967 totaled 1.22 billion pounds, down from 1.27 billion pounds in 1966 and 1.28 billion pounds in 1955. Based on the formula required by law, the 1969 price supports for tobacco, which usually determine the price to farmers, will be about 4 per cent above the 1968 level.

\section{Food Prices}

Of major significance to the nation's welfare has been the growth in supplies of farm products, which has tended to meet a rising demand at relatively stable prices. For example, prices received for meat animals have increased only 2 per cent since 1950 , and average prices received for poultry and eggs have declined. Output and consumption of these commodities have risen at a high rate. Meat production rose more than 50 per cent and poultry output rose about 2.5 times during the period. This rapid growth in output at relatively constant prices is the result of major gains in farming efficiency. These gains from new technology have increased the supplies of farm products with each increase in demand. A major beneficiary has been the consuming sector, as rising quantities of high-quality food have moved into the marketing channels at relatively constant prices. The rising consumption of meat per capita is an example of consumer gains (Table 1). Most of the food price increases that have been experienced in recent years have reflected rising processing and marketing costs rather than changes in prices received by farmers.

These trends of rising efficiency in farm commodity production, relatively stable farm commodity prices, and rising food costs are expected to continue in 1969. 